\title{
HepG2/erythrocyte glucose transporter (GLUT1) gene in NIDDM: a population association study and molecular scanning in Japanese subjects
}

\author{
T. Tao, Y. Tanizawa, A. Matsutani, A. Matsubara, T. Kaneko, K. Kaku \\ Third Department of Internal Medicine, Yamaguchi University School of Medicine, Ube, Yamaguchi, Japan
}

\begin{abstract}
Summary To evaluate the role of mutations in the glucose transporter (GLUT1) gene in Japanese patients with non-insulin-dependent diabetes mellitus (NIDDM), we first conducted a population association study using the XbaI polymorphism of the gene. A polymerase chain reaction (PCR)-based assay was developed and used for the analysis. When analysed in 91 diabetic patients and 87 non-diabetic control subjects, the distribution of the genotype frequency was significantly different between the two groups $(p=0.0025)$. The $(-)$ allele was significantly associated with NIDDM (odds ratio $2.317,95 \%$ confidence interval 1.425-3.768). To identify possible mutation(s) in the GLUT1 gene, which was in linkage disequilibrium with the $(-)$ allele, all ten exons of the gene were analysed by PCR single-strand conformation polymorphism (SSCP) analysis in 53 diabetic patients with at least one (-) allele. Variant SSCP patterns were detected in exons $2,4,5,7,9$ and 10 . Se-
\end{abstract}

quence analysis revealed that all the variants represented silent mutations. One of the variants in exon 2, GCT $\left(\mathrm{Ala}^{15}\right) \rightarrow \mathrm{GCC}(\mathrm{Ala})$, created a HaeIII restriction site. This polymorphism was common in Japanese subjects with heterozygosity of 0.36 and polymorphism information content 0.29 . We conclude that the structural mutation of GLUT1 is rare and not likely to be a major genetic determinant of NIDDM in Japanese subjects. The XbaI ( - ) allele of the GLUT1 gene appeared to be a genetic marker of NIDDM in Japanese subjects. The possibility of the presence of mutation(s) in the regulatory region of the gene or in another locus nearby could not be excluded. [Diabetologia (1995) 38: 942-947]

Key words Non-insulin-dependent diabetes mellitus, genetics, GLUT1, single-strand conformation polymorphism, mutation.
Non-insulin-dependent diabetes mellitus (NIDDM) is a metabolic disorder characterised by chronic hyperglycaemia due to impaired fuel metabolism. Strong familial aggregation of the disease suggests that genetic components play a major role as determinants of susceptibility to the disease [1]. "Candidate

Received: 5 October 1994 and in revised form: 26 January 1995

Corresponding author: Dr. K. Kaku, The Third Department of Internal Medicine, Yamaguchi University, School of Medicine, 1144 Kogushi, Ube, Yamaguchi, 755, Japan

Abbreviations: NIDDM, Non-insulin-dependent diabetes mellitus; PCR, polymerase chain reaction; SSCP, single strand conformation polymorphism; BMI, body mass index; RFLP, restriction fragment length polymorphism; TRE, TPA-responsive elements; GLUT1, glucose transporter 1. genes", the mutation of which could determine the susceptibility to NIDDM, have been intensively studied. Recently, mutations in the glucokinase $[2,3]$ and mitochondrial genes [4-6] were found in a subset of NIDDM. The inherited defects in the greater part of the common form of NIDDM, however, remain to be identified.

HepG2/erythrocyte glucose transporter (GLUT1) is a member of the facilitative glucose transporter family. GLUT1 is the most widely expressed member of this family and transports glucose across the barrier between body tissues and blood supply [7]. It may be responsible for basal constitutive glucose uptake in most tissues; thus, defective GLUT1 could disturb basal glucose uptake and might result in chronic hyperglycaemia. The association between the 
Table 1. Clinical characteristics of subjects for the analysis of GLUT1 gene

\begin{tabular}{lccccc}
\hline & $n$ & Age (years) & Sex (\% male) & $\begin{array}{l}\text { Positive family } \\
\text { history }(\%)\end{array}$ & BMI $\left(\mathrm{kg} / \mathrm{m}^{2}\right)$ \\
\hline NIDDM subjects & 91 & $58.5 \pm 11.3^{\mathrm{a}}$ & 41.8 & 38.5 & $22.7 \pm 3.8$ \\
Control subjects & 87 & $48.7 \pm 8.4^{\mathrm{a}}$ & 40.2 & 0 & $22.3 \pm 3.2$ \\
\hline
\end{tabular}

Values are mean $\pm \mathrm{SD} ;{ }^{\mathrm{a}} p<0.01$

GLUT1 gene and NIDDM has been studied using restriction fragment length polymorphism (RFLP) of the gene in several racial groups including Japanese [8-13]. The results, however, are inconclusive. Some have reported positive associations $[8,13]$, but others reported negative $[9,10-12,14]$, even in the same racial groups. Linkage was not found in familial NIDDM pedigrees $[15,16]$ or in Caucasian diabetic sib-sets [17]. These results suggested that mutations in the GLUT1 gene did not play a major role in the development of NIDDM. Linkage analysis, however, may not be definitive in the heterogeneous diseases with an unknown mode of inheritance; minor roles also could not be ruled out.

The Japanese are one of the populations in which the association between the GLUT1 polymorphism and NIDDM has been suggested previously [8]. We first re-examined the association in our study population. Finding that the $\mathrm{XbaI}(-)$ allele of the gene was a genetic marker of NIDDM, we analysed the GLUT1 gene in the diabetic patients at single nucleotide level using polymerase chain reaction-single strand conformation polymorphism (PCR-SSCP) analysis to evaluate directly the role of the GLUT1 gene in the development of NIDDM.

\section{Subjects and methods}

Subjects. NIDDM patients and non-diabetic control subjects were chosen randomly from the subjects we examined in a previous study [18]. All subjects were recruited from the outpatient clinics at Yamaguchi University Hospital and affiliated hospitals. They were unrelated Japanese over the age of 40 years, living in Yamaguchi Prefecture. Individuals with NIDDM met the diagnostic criteria of the World Health Organization. Non-diabetic subjects had a random plasma glucose of less than $6.7 \mathrm{mmol} / \mathrm{l}$ and claimed no personal or family history of diabetes. At the time of the recruitment, informed consent was obtained from each individual according to a protocol approved by the Human Studies Committee. Clinical characteristics of the subjects for the current study are summarized in Table 1 . Control subjects were younger $(p<0.01)$ than diabetic patients. There was no difference between the two groups in gender and body mass index (BMI). None of the parameters were different from those of the subjects in the previous study in either NIDDM or control groups.

Genomic DNA was extracted from leukocytes as reported previously [9].

Restriction fragment length polymorphism (RFLP) analysis. XbaI RFLP of the human GLUT1 gene [19] was detected by
Southern blot analysis of genomic DNA [9]. Because the classic RFLP analysis using Southern Blotting was laborious and time consuming, we established a PCR-based detection system. The polymorphic XbaI site was localized in the second intron of the gene by restriction analysis of a human GLUT1 genomic clone (kindly provided by Dr. M. Mueckler, Washington University, St. Louis, Mo., USA). The fragment containing the polymorphic XbaI site was subcloned and the flanking DNA sequences were determined. A $5^{\prime}$ primer (TGTGCAACCCATGAGCTAA) and a $3^{\prime}$ primer (CCTGGTCTCATCTGGATTCT) were synthesized on the DNA synthesizer (Model 392, Applied Biosystems Japan, Urayasu, Japan). A $1.1 \mathrm{~kb}$ DNA fragment including the polymorphic XbaI site was PCR amplified in $20 \mu \mathrm{l}$ containing $250 \mathrm{ng}$ of genomic DNA, $10 \mathrm{pmol}$ each primer, $0.2 \mathrm{mmol} / 1$ each $\mathrm{dNTP}, 10 \mathrm{mmol} / 1$ Tris-HCl (pH 8.3), $50 \mathrm{mmol} / \mathrm{l} \mathrm{KCl}, 1.5 \mathrm{mmol} / 1 \mathrm{MgCl}_{2}, 0.01 \%$ gelatin and 0.25 unit AmpliTaq DNA polymerase (Perkin Elmer/Cetus, Norwalk, Conn., USA). After 30 cycles of amplification consisting of denaturation at $94^{\circ} \mathrm{C}$ for $1 \mathrm{~min}$, annealing at $55^{\circ} \mathrm{C}$ for $1 \mathrm{~min}$, extension at $72^{\circ} \mathrm{C}$ for $1 \mathrm{~min}$ and $20 \mathrm{~s}$, in a thermocycler (Program Temp Control System PC-700, ASTEC Co., Fukuoka, Japan), the products were purified using Prep-A-Gene DNA purification kit (Bio-Rad Laboratories, Richmond, Calif., USA), digested with 10-fold excess XbaI for $3-4 \mathrm{~h}$ and electrophoresed on a $1.2 \%$ agarose gel. XbaI RFLP was detected by ethidium bromide staining.

A silent mutation in exon 2 created a HaeIII site. This polymorphism was also detected by PCR-RFLP assay. Exon 2 was amplified using the PCR primers for the SSCP analysis (see below). Amplified products were digested with HaeIII followed by the electrophoresis in $2.8 \%$ agarose gel as for the XbaI polymorphism.

SSCP analysis of the GLUT1 gene. Ten sets of oligonucleotide primers were synthesized flanking the coding regions of each of 10 exons of the human GLUT1 gene (Table 2, [20]; a part of intronic sequences was kindly provided by Dr. G. I. Bell, University of Chicago, Chicago, Ill., USA).

PCR amplification was conducted in a $10-\mu$ l volume containing $100 \mathrm{ng}$ genomic DNA, 2 pmol each primer, $0.1 \mathrm{mmol} / \mathrm{l}$ each dNTP, $10 \mathrm{mmol} / 1$ Tris- $\mathrm{HCl}$ (pH 8.3), $50 \mathrm{mmol} / \mathrm{l} \mathrm{KCl}$, $2 \mathrm{mmol} / 1 \mathrm{MgCl}_{2}, 0.01 \%$ gelatin, 0.25 unit AmpliTaq DNA polymerase and $0.67 \mu \mathrm{Ci}$ of $\alpha-\left[{ }^{32} \mathrm{P}\right] \mathrm{dCTP}(3,000 \mathrm{C} / \mathrm{mmol}$, Amersham, Tokyo, Japan). After an initial denaturation at $94^{\circ} \mathrm{C}$ for $3 \mathrm{~min}, 30$ cycles of amplification were performed with denaturation at $94^{\circ} \mathrm{C}$ for $1 \mathrm{~min}$, annealing for $1 \mathrm{~min}$ at the temperatures given in Table 2 , and extension at $72^{\circ} \mathrm{C}$ for $1 \mathrm{~min}$, followed by a final extension at $72^{\circ} \mathrm{C}$ for $10 \mathrm{~min}$.

SSCP was performed essentially using the method of Orita et al. [21]. Ten microlitres of the PCR products was mixed with $30 \mu \mathrm{l}$ of $95 \%$ formamide, $20 \mathrm{mmol} / 1 \mathrm{EDTA}, 0.05 \%$ bromophenol blue and xylene cyanol. Immediately before electrophoresis, samples were heat-denatured at $94^{\circ} \mathrm{C}$ for $3 \mathrm{~min}$. Aliquots of the samples $(1.5 \mu \mathrm{l})$ were electrophoresed under two different conditions: 1 ) $5 \%$ polyacrylamide (49:1, acrylamide: $\mathrm{N}, \quad \mathrm{N}$-methylene-bis-acrylamide) gel in $1 \times \mathrm{TBE}$ [90 $\mathrm{mmol} / 1$ Tris-borate $(\mathrm{pH} 8.3), 2 \mathrm{mmol} / 1 \mathrm{EDTA}]$ at $5-7 \mathrm{~W}$ 
Table 2. PCR primers used for the SSCP analysis of GLUT1 gene

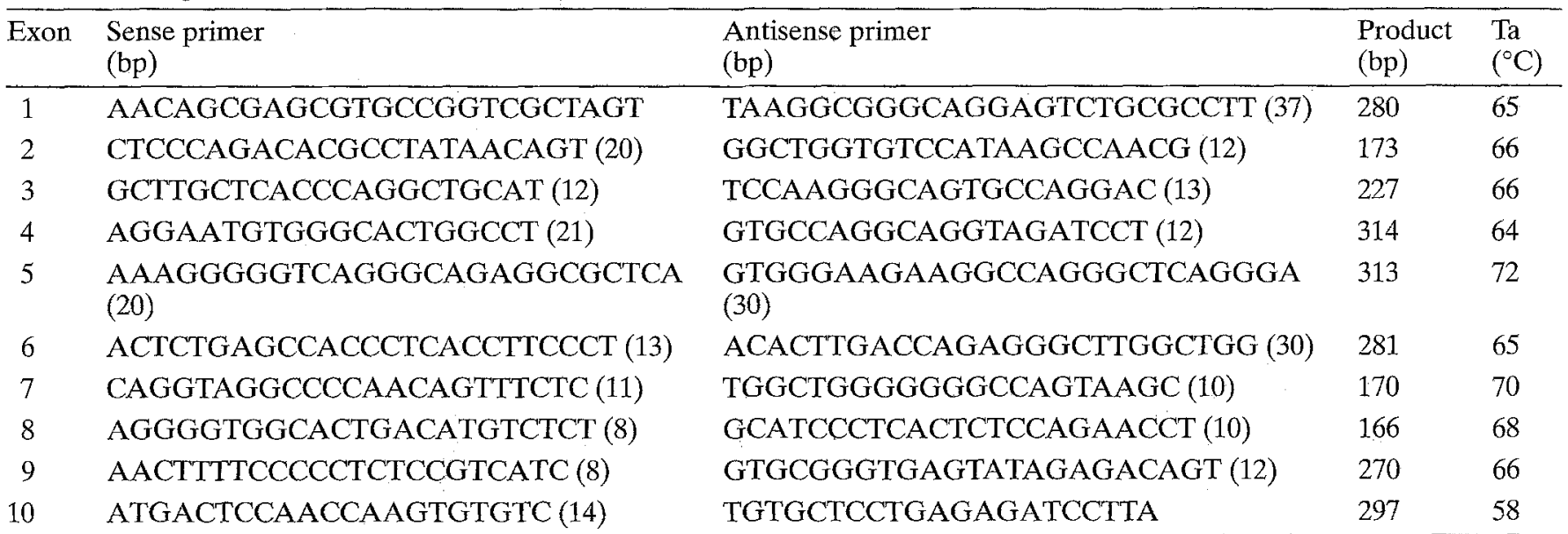

Number of nucleotides between the end of each PCR primer and the corresponding exon-intron boundary in parentheses. The sense primer of exon 1 and the antisense primer of exon

for $12 \mathrm{~h}$ or $30 \mathrm{~W}$ for $3-4 \mathrm{~h}$; 2) $5 \%$ polyacrylamide gel with $10 \%$ glycerol in $1 \times \mathrm{TBE}$ at $5-7 \mathrm{~W}$ for $12 \mathrm{~h}$, both at room temperature. After the electrophoresis, gels were dried and exposed to X-ray film with an intensifying screen for $16-24 \mathrm{~h}$ at $-80^{\circ} \mathrm{C}$.

DNA sequencing and analysis. Exons were PCR amplified from $200 \mathrm{ng}$ of genomic DNA in a $20-\mu 1$ volume. Products were electrophoresed on $1.2 \%$ NuSieve GTG Agarose (FMC BioProducts, Rockland, Me., USA) to ensure a single specific product. The DNA-containing gel was cut out and digested by $\beta$-Agarase I (New England Biolabs, Beverly, Mass., USA) at $40^{\circ} \mathrm{C}$ for $2 \mathrm{~h}$. After the digestion, DNA was recovered by ethanol precipitation.

DNA sequencing was performed using Taq Dye Deoxy Terminator Cycle Sequencing Kit and model 373A DNA Sequencer (Applied Biosystems) according to the manufacturer's instructions.

Possible transcriptional regulatory elements near the polymorphic XbaI site in the second intron were searched by a computer program GENETYX-MAC version 6.01 (Software Development Co., Ltd., Tokyo, Japan).

\section{Statistical analysis}

Statistical significance of difference between groups in quantitative variables was analysed by unpaired (two-tailed) $t$-tests. Associations between the polymorphic markers in the GLUT1 gene and NIDDM was assessed by Fisher's exact test or the chi-square test.

\section{Results}

XbaI RFLP analysis at the GLUT1 locus. Southern blotting revealed a two-allele polymorphism of $5.9 \mathrm{~kb}(+$ allele $)$ and $6.2 \mathrm{~kb}$ (- allele) as reported previously $[9,19]$. To establish a PCR-based detection system, we localized the polymorphic XbaI site in the second intron and determined the flanking sequence (Fig. 1). PCR-RFLP produced three bands of different sizes (Fig. 2). A $1.1 \mathrm{~kb}$ band corresponds to
10 are in the $5^{\prime}$ and $3^{\prime}$ untranslated regions, respectively. Ta, annealing temperatures

tctaga $_{1}$ atcc taagatcaag gttcgagagg ccacatccag ccagcagcct gtttgtgcaa cccatgagct aa 2 caatggtt ttacatttta caaggttgag aaaaaagaac aatgagtgac agaggccata tgtggctcac agaccctacc taatggattc tagctagcet tttacataaa atgtttacce cagtccgget ctggagcact ttgacttgca tgctccctac ttacagggaa ctcaccacct gtaaggtggg cagcetcata ccctgaagtc taGa 3 aagctc ttccttccce tgagctggag tctggcectg gcacetctgc cetctgggge tacagagtge tgggttcctc tgccaggagc agccgagcag ggtctggaga ctagctttat tccetgagge aggcecgtag ttccttcagg ttcctccta ctcttacatt cttagggtaa tgatttctgg caatttcaaa atggaaacc ttgtccctaa ggctcctccg aaagaggtga cttctttct tgagagagca acagtgacag cagtaacagc ttacccatgt gccaggcagt gttcgccgec tcatgcccet

Fig. 1. Nucleotide sequence flanking the polymorphic XbaI site in the second intron of the human GLUT1 gene. XbaI sites $(1,3)$ and the site of the $5^{\prime}$ primer for the PCR-RFLP analysis (2) are underlined. $G$ to $T$ transversion in the second XbaI recognition site (3, capitalized) abolishes the recognition site. The $3^{\prime} \mathrm{PCR}$ primer locates about $1.1 \mathrm{~kb}$ downstream of the 5 primer

the $(-)$ allele, and a set of $0.9 \mathrm{~kb}$ and $0.2 \mathrm{~kb}$ bands correspond to $(+)$ allele. The results from the two methods were identical.

Observed genotypic frequency for the Xbal polymorphism did not differ from that predicted from Hardy-Weinberg equilibrium in the control or the diabetic group. Heterozygosity of the polymorphism in the control subjects was 0.303 , and the polymorphism information content was 0.257 .

Distribution of the genotype frequency was significantly different between the diabetic patients and the non-diabetic control subjects (Table 3, chi-square was $11.974, d f=2, p=0.0025)$. When the allele fre- 


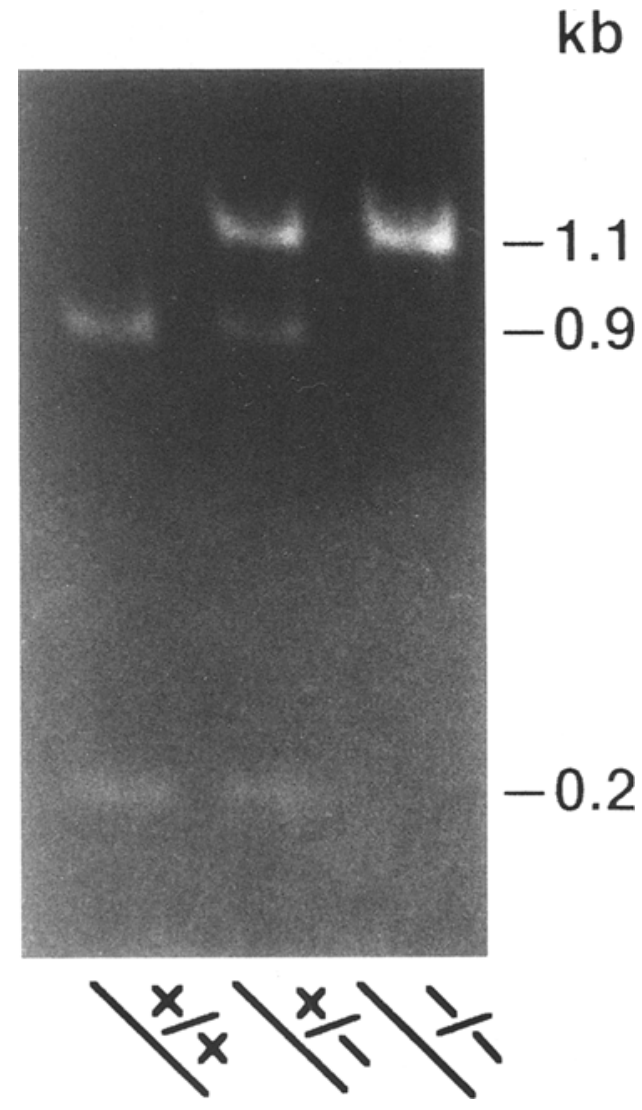

Fig. 2. XbaI RFLP of human GLUT1 gene detected by PCRRFLP analysis. Sizes of the fragments are shown in $\mathrm{kb}$ on the right. Genotypes assigned for each individual are shown below the lanes

quency was compared, the (-) allele was significantly associated with NIDDM (odds ratio $2.317,95 \%$ confidence interval 1.425-3.768, Table 3).

Clinical characteristics were compared among groups with each genotype in the diabetic patients. The average BMI did not differ (data not shown). $\mathrm{HbA}_{1 \mathrm{c}}$ in (+/-) group was marginally lower than in $(+/+)$ group $(7.9 \pm 1.7 \%$ vs $8.7 \pm 2.0 \%$, mean $\pm S D$, $p<0.05)$.

Variation of the GLUT1 gene. From the population association study, the (-) allele of the XbaI RFLP appeared to be a risk factor for NIDDM in Japanese subjects. Since Murakami et al. [22] suggested that the TPA-responsive elements (TRE) in the second intron of the mouse GLUT1 gene regulate gene transcription, we examined the possibility that the Xbal polymorphism itself might be involved in the transcriptional gene regulation. The polymorphism did not create or abolish any known regulatory elements including TRE (Fig. 1 and data not shown).

We then assessed the possibility that the increased risk was due to the mutation(s) in the coding region of the GLUT1 gene by direct analysis of the gene. All of the ten exons of the GLUT1 gene were
Table 3. Genotypic and allelic frequencies of XbaI RFLP

\begin{tabular}{|c|c|c|}
\hline & NIDDM subjects & Control subjects \\
\hline $\begin{array}{l}\text { Genotype }^{a} \\
+/+ \\
+/- \\
-1-\end{array}$ & $\begin{array}{l}38(0.42) \\
42(0.46) \\
11(0.12)\end{array}$ & $\begin{array}{r}56(0.64) \\
29(0.33) \\
2(0.02)\end{array}$ \\
\hline Total & 91 & 87 \\
\hline $\begin{array}{l}\text { Allele }^{b} \\
+ \\
-\end{array}$ & $\begin{array}{r}118(0.65) \\
64(0.35)\end{array}$ & $\begin{array}{r}141(0.81) \\
33(0.19)\end{array}$ \\
\hline Total & 182 & 174 \\
\hline
\end{tabular}

screened by PCR-SSCP in 53 NIDDM patients with at least one XbaI (-) allele. Variant SSCP patterns were detected in exons 2, 4, 5, 7, 9 and 10. All samples showing variant patterns were subjected to direct sequencing and nucleotide substitutions were identified (Table 4). All the variants were silent mutations without amino acid substitution. Although the nucleotide substitutions in exons 4, 5, 7 and 10 created GT or AG dinucleotides, the flanking sequences did not match well with the known splicing consensus. Therefore it was unlikely that these changes altered GLUT1 mRNA processing by activating cryptic splicing.

One of the silent mutations in exon 2 , $\mathrm{T}$ to $\mathrm{C}$ transition at nucleotide 45 in the codon for $\mathrm{Ala}^{15}$, is relatively common in the Japanese population. The $\mathrm{C}$ allele, a variant from the reported sequence [23], has been found to be more common in the Japanese population. This transition created an HaeIII restriction site and the polymorphism was detectable by the PCR-RFLP method. When exon 2 was PCR amplified and digested with HaeIII, the (-) allele (with $\mathrm{T}$ at nucleotide 45) gave a single 138 bp band on agarose gel electrophoresis, whereas the $(+)$ allele (with C at 45) gave a set of 103 bp and 35 bp bands. When analysed in NIDDM patients and control subjects, the allelic and genotypic frequencies did not differ between these two groups (Table $5, p=0.3805$, Fisher's exact test). The heterozygosity of the polymorphism in the non-diabetic subjects was 0.359 and the polymorphism information content 0.291 .

\section{Discussion}

Among the members of facilitative glucose transporters, liver/islet glucose transporter (GLUT2) and insulin-regulatable glucose transporter (GLUT4) were extensively studied as candidates for genetic determinants of susceptibility to NIDDM [10, 15, 24-29]. Al- 
Table 4. SSCP analysis of GLUT1 gene in NIDDM patients

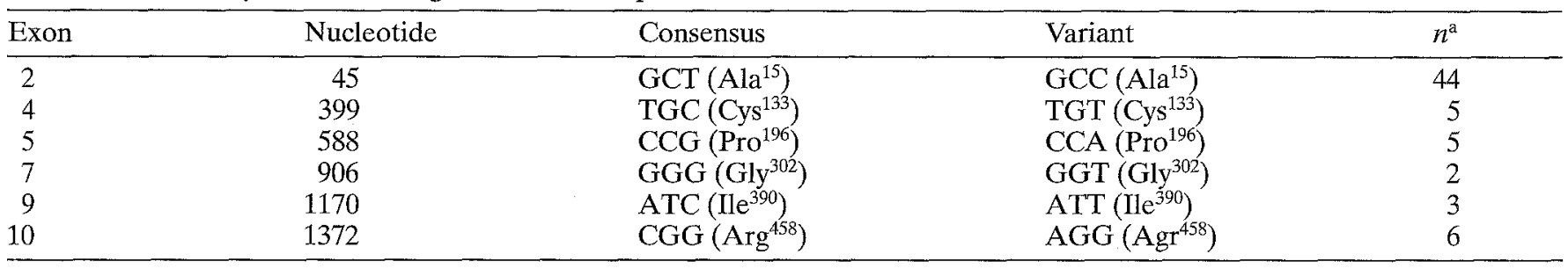

Nucleotide, amino acid numbers and consensus sequences published previously [23].

a Number of patients with at least one variant allele. Genotypic and allelic frequencies of the common polymorphism in exon 2 (T/C) are shown in Table 5. Other rare variants in exons $4,5,7,9,10$ were all observed in heterozygotes with the consensus sequence
Table 5. Genotypic and allelic frequencies of HaeIII RFLP in exon 2 of the GLUT1 gene

\begin{tabular}{lcc}
\hline & NIDDM patients & Control subjects \\
\hline Genotype $^{\mathrm{a}}$ & $46(0.54)$ & $46(0.57)$ \\
$+/+$ & $30(0.35)$ & $32(0.40)$ \\
$+/-$ & $9(0.11)$ & $3(0.04)$ \\
$-/-$ & 85 & 81 \\
\hline Total & & \\
Allele & & $124(0.77)$ \\
+ & $122(0.72)$ & $38(0.23)$ \\
\hline & $48(0.28)$ & 162 \\
\hline Total & 170 & \\
\hline
\end{tabular}

(+) allele corresponds to $\mathrm{GCC}\left(\mathrm{Ala}^{15}\right)$ and (-) allele to GCT $\left(\right.$ Ala $\left.^{15}\right)$ in Table 4.

${ }^{a} p=0.2265\left(\chi^{2}=2.97, d f=2\right)$ between NIDDM and control subjects;

${ }^{\mathrm{b}} p=0.3805$ (Fisher's exact test) between NIDDM and control subjects

though a defective GLUT2 was identified in one single patient with NIDDM [27, 30], the mutations in these glucose transporters appeared to be rare and do not play a major role in the development of NIDDM. The role of HepG2/erythrocyte (GLUT1) glucose transporter, which is ubiquitously expressed and facilitates basal glucose transport into the cells, is less clear. The gene has not been studied at a single nucleotide level.

$\mathrm{Li}$ et al. [8] reported an association between NIDDM and the XbaI polymorphism of the GLUT1 gene in Japanese subjects. To further assess the role of GLUT1 mutation in NIDDM, we first tested whether the association could be replicated in our population. Our data also showed that the XbaI (-) allele was significantly associated with NIDDM (odds ratio $2.317,95 \%$ confidence interval $1.425-$ 3.768).

To examine whether the increased risk of NIDDM with the XbaI (-) allele was due to mutation(s) in the GLUT1 gene, we analysed all ten exons of the gene by PCR-SSCP in the diabetic patients with at least one (-) allele. We found only several silent mutations without functional significance. Although gross rear- rangements of the gene, including insertion or deletion, could not be detected by PCR-SSCP analysis, we did not see aberrant bands other than those expected for the RFLPs during the course of XbaI and other RFLP analyses of the gene by Southern blot analysis. We chose 53 patients with at least one XbaI $(-)$ allele for the SSCP analysis; 42 of whom were heterozygous at the locus, however, having one XbaI (+) allele. Thus it is unlikely that we have missed a common mutation in linkage disequilibrium with the $\mathrm{XbaI}(+)$ allele in Japanese subjects. These results indicate that structural changes in GLUT1 are not a major determinant of the susceptibility to NIDDM in Japanese subjects, although we cannot exclude a small possibility that we have missed the mutation because of the limitation of the sensitivity of the analysis.

We observed an association between the Xbal polymorphism of the GLUT1 gene and NIDDM in Japanese subjects, but were unable to identify an attributable mutation in the coding region. Although a population association study may be useful in the genetic analysis of complex diseases like NIDDM, it suffers from methodological deficiencies which could lead to a spurious observation $[14,31]$. Thus, our conflicting results may be explained by the spurious association. The genotypic and allelic frequency distributions of the polymorphism in our samples however were very similar to those observed by $\mathrm{Li}$ et al. [8] in a smaller sample. The possibility that the association could be attributable to a mutation in the undefined regulatory region of the gene or in an adjacent gene must not be discarded. In this regard the mouse diabetic gene (db) and rat obesity gene (fa) were localized in a region including GLUT1, Cjun and Lck genes, all of which also made a cluster on chromosome 1 (1p 31-36) in human $(32,33)$.

We conclude that the structural mutation of the GLUT1 glucose transporter is rare, and is unlikely to be a major determinant of genetic susceptibility to NIDDM in Japanese subjects. The XbaI ( - ) allele of the GLUT1 gene appeared to be a genetic marker of NIDDM in Japanese subjects. The possibility of the presence of mutation(s) in the regulatory region of the gene or in the loci nearby could not be excluded. 
Acknowledgements. This work was partially supported by grants from the Ministry of Education, Science and Culture of Japan (K.K. and A.M.) and from the International Association of Lions Clubs (T.K. and K.K.). We thank Dr. M. Mueckler (Washington University, St.Louis, Mo., USA) for providing GLUT1 genomic clones, and Dr. G. I. Bell (University of Chicago, Chicago, Ill., USA) for the partial intronic sequences of human GLUT1 gene. We are indebted to Ms. Y. Kora-Miura for technical assistance and to Ms. Y. Nakamatsu for preparing the manuscript.

\section{References}

1. Barnett ET, Eff C, Leslie RDG, Pyke DA (1981) Diabetes in identical twins. A study of 200 pairs. Diabetologia 20: $87-93$

2. Froguel Ph, Zouali H, Vionnet $\mathrm{N}$ et al. (1993) Familial hyperglycemia due to mutations in glucokinase. Definition of a subtype of diabetes mellitus. N Engl J Med 328: 697-702

3. Stoffel M, Patel P, Lo YMD et al. (1992) Missense glucokinase mutation in maturity-onset diabetes of the young and mutation screening in late-onset diabetes. Nature Genetics 2: $153-156$

4. Ballinger SW, Shoffner JM, Hedaya EV et al. (1992) Maternally transmitted diabetes and deafness associated with a $10.4 \mathrm{~kb}$ mitochondrial deletion. Nature Genetics 1: 11-15

5. van den Ouweland JMW, Lemkes HHPJ, Ruitenbeek W et al. (1992) Mutation in mitochondrial tRNA ${ }^{\mathrm{Leu}(U U \mathrm{R})}$ gene in a large pedigree with maternally transmitted type II diabetes mellitus and deafness. Nature Genetics 1: 368-371

6. Reardon W, Ross RJM, Sweeney MG et al. (1992) Diabetes mellitus associated with a pathogenic point mutation in mitochondrial DNA. Lancet 340: 1376-1379

7. Mueckler M (1994) Facilitative glucose transporters. Eur J Biochem 219: 713-725

8. Li SR, Baroni MG, Oelbaum RS, Stock J, Galton DJ (1988) Association of genetic variant of glucose transporter with non-insulin-dependent diabetes mellitus. Lancet II: 368 370

9. Kaku K, Matsutani A, Mueckler M, Permutt MA (1990) Polymorphism of He pG2/Erythrocyte glucose-transporter gene. Diabetes 39: 49-56

10. Alcolado JC, Baroni MG (1992) Restriction fragment length polymorphisms at the GLUT4 and GLUT1 gene loci in type 2 diabetes. Diabet Med 9: 58-60

11. Cox NJ, Xiang KS, Bell GI, Karam JH (1988) Glucose transporter gene and non-insulin-dependent diabetes. Lancet II: 793-794

12. Li SR, Oelbaum RS, Bouloux PMG, Stocks J, Baroni MG, Galton DJ (1990) Restriction site polymorphisms at the human HepG2 glucose transporter gene locus in Caucasians and Italian subjects with non-insulin-dependent diabetes mellitus. Hum Hered 40: 38-44

13. Baroni MG, Oelbaum RS, Pozzilli P et al. (1992) Polymorphisms at the GLUT1 (HepG2) and GLUT4 (muscle/adipocyte) glucose transporter genes and non-insulin-dependent diabetes mellitus (NIDDM). Hum Genet 88: 557-561

14. Cox NJ, Bell GI (1989) Disease associations. Chance, artifact or susceptibility genes? Diabetes 38: 947-950

15. O'Rahilly S, Patel P, Wainscoat JS, Turner RC (1989) Analysis of the HepG2/erythrocyte glucose transporter locus in a family with type 2 (non-insulin-dependent) diabetes and obesity. Diabetologia 32: 266-269

16. Elbein SC, Hoffman MD, Matsutani A, Permutt MA (1992) Linkage analysis of GLUT1 (HepG2) and GLUT2 (liver/islet) genes in familial NIDDM. Diabetes 41: 16601667

17. Baroni M, Alcolado JC, Gragnoli C et al. (1994) Affected sib-pair analysis of the GLUT1 glucose transporter gene locus in non-insulin-dependent diabetes mellitus (NIDDM): evidence for no linkage. Hum Genet 93: 675-680

18. Noda K, Matsutani A, Tanizawa Y et al. (1993) Polymorphic microsatellite repeat markers at the glucokinase gene locus are positively associated with non-insulin dependent diabetes mellitus in Japanese. Diabetes 42: 1147-1152

19. Shows TB, Eddy RL, Byers MG et al. (1987) Polymorphic human glucose transporter gene (GLUT1) on chromosome 1p31.3-p35. Diabetes 36: 546-549

20. Fukumoto H, Seino S, Imura H, Seino Y, Bell GI (1988) Characterization and expression of human HepG2/Erythrocyte glucose-transporter gene. Diabetes 37: 657-661

21. Orita M, Suzuki Y, Sekiya T, Hayashi K (1989) Rapid and sensitive detection of point mutations and DNA polymorphism using the polymerase chain reaction. Genomics 5: $874-879$

22. Murakami T, Nishiyama T, Shirotani Tet al. (1992) Identification of two enhancer elements in the gene encoding the type 1 glucose transporter from the mouse which are responsive to serum, growth factor and oncogenes. J Biol Chem 267: 9300-9306

23. Mueckler M, Caruso C, Baldwin SA et al. (1985) Sequence and structure of a human glucose transporter. Science 229: 941-945

24. Matsutani A, Koranyi L, Cox N, Permutt MA (1990) Polymorphism of GLUT2 and GLUT4 genes. Use in evaluation of genetic susceptibility to NIDDM in Blacks. Diabetes 39: 1534-1542

25. Patel P, Lo Y-MD, Hattersley A et al. (1992) Linkage analysis of maturity onset diabetes of the young with microsatellite polymorphism. No linkage to ADA or GLUT2 genes in two families. Diabetes 41: 962-967

26. Janssen R, Bogardus C, Takeda J, Knowler WC, Thompson DB (1994) Linkage analysis of acute insulin secretion with GLUT2 and glucokinase in Pima Indians and the identification of a missense mutation in GLUT2. Diabetes 43: $558-563$

27. Tanizawa Y, Riggs AC, Chiu KC̀ et al. (1994) Variability of the pancreatic islet beta cell/liver (GLUT2) glucose transporter gene in NIDDM patients. Diabetologia 37: 420-427

28. Kusari J, Verma US, Buse JB, Henry RR, Olefsky JM (1991) Analysis of the gene sequences of the insulin receptor and the insulin-sensitive glucose transporter (GLUT-4) in patients with common-type non-insulin-dependent diabetes mellitus. J Clin Invest 88: 1323-1330

29. Choi W-H, O'Rahilly S, Buse JB et al. (1991) Molecular scanning of insulin-responsive glucose transporter (GLUT4) gene in NIDDM subjects. Diabetes 40: 17121718

30. Mueckler M, Kruse M, Strube M, Riggs AC, Chiu KC, Permutt MA (1994) A mutation in the GLUT2 glucose transporter gene of a diabetic patient abolishes transport activity. J Biol Chem 269: 17765-17767

31. Lander ES, Shork NJ (1994) Genetic dissection of complex trait. Science 265: 2037-2048

32. Bahary N, Leibel RL, Joseph L, Friedman JM (1990) Molecular mapping of the mouse $\mathrm{db}$ mutation. Proc Natl Acad Sci USA 87: 8642-8646

33. Truett GE, Bahary N, Friedman JM, Leibel RL (1991) Rat obesity gene fatty (fa) maps to chromosome 5: evidence for homology with the mouse gene diabetes $(\mathrm{db})$. Proc Natl Acad Sci USA 88: 7806-7809 